\title{
Konstruksi Hukum Terhadap Penetapan Bunga Tinggi pada Investasi yang Diselenggarakan Koperasi Simpan Pinjam
}

\author{
Yeti Sumiyati ${ }^{1}$, Ratna Januarita ${ }^{2}$, Tatty A. Ramli ${ }^{3}$, Efik Yusdiansyah ${ }^{4}$ \\ 1Fakultas HukumUniversitas Islam Bandung, E-mail: yeti@unisba.ac.id, \\ yeti74sumiyatibdg@gmail.com \\ 2Fakultas Hukum Universitas Islam Bandung, E-mail: ratna.januarita@unisba.ac.id \\ 3Fakultas Hukum Universitas Islam Bandung, E-mail: tattyramli@gmail.com \\ ${ }^{4}$ Fakultas Hukum Universitas Islam Bandung, E-mail: efik@unisba.ac.id
}

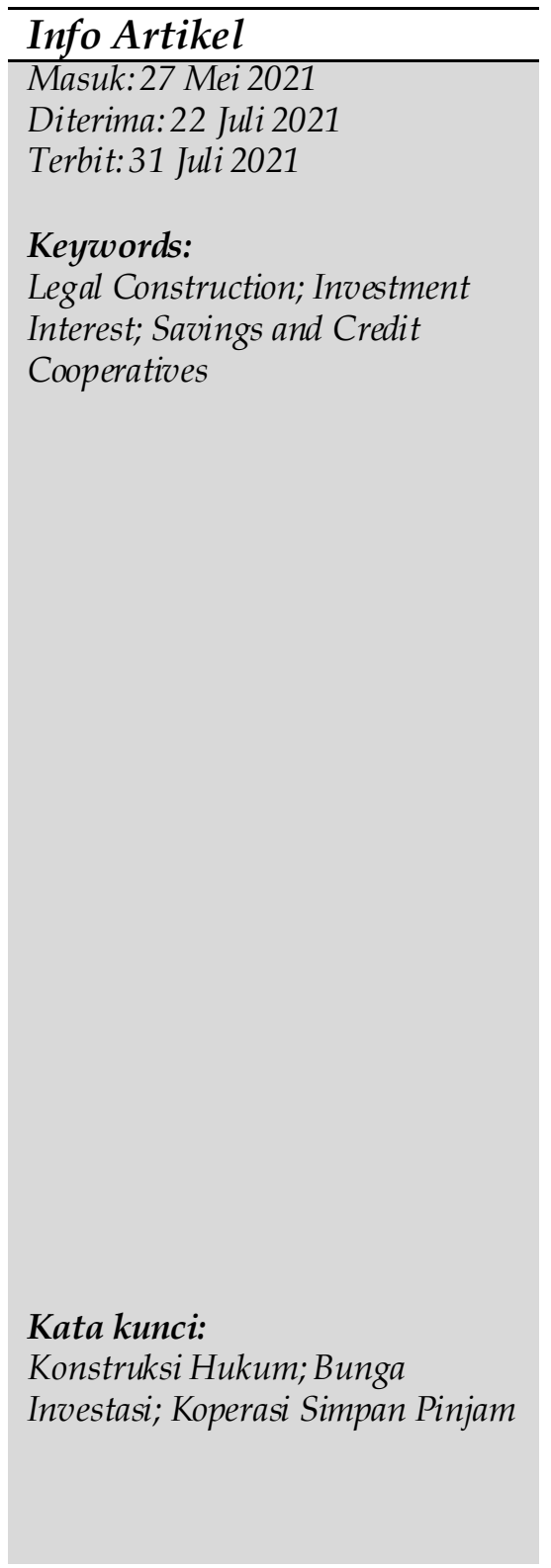

\begin{abstract}
The purpose of this research is to examine the adequacy of laws and regulations governing investment implementation by the Savings and Credit Cooperative (KSP) and formulate legal constructs related to the determination of investment interest rates by KSP through the regulations of the Indonesian Deposit Insurance Corporation (IDIC/LPS) concerning the Determination of the Deposit Insurance Interest Rate in the form of IDIC Regulation (Surat Edaran). The research method uses a normative juridical approach, descriptive-analytical research specifications, the systematic interpretation and the legal construction of analogy. The results showed that the statutory regulations governing investments made by KSP were insufficient, especially in the section relating to the determination of investment interest rates. There were still many KSPs that set high interest in their investment programs. Law Number 11 of 2020 concerning Job Creation and Government Regulation Number 7 of 2021 concerning Ease, Protection, and Empowerment of Cooperatives and Micro, Small and Medium Enterprises also does not accommodate provisions regarding investment programs that KSP can carry out. It is feared that several new provisions in the two regulations will lead to high-interest investment practices by KSP that prioritize the interests of their institutions over the welfare of members. Through the analysis of legal construction, it was found that the IDIC Regulation (Surat Edaran) regarding the Determination of the Deposit Insurance Interest Rate at Commercial Banks and Rural Banks can be used as a reference by the Ministry of Cooperatives and SMEs to encourage KSP to set investment interest rates fairly.
\end{abstract}

\begin{tabular}{l}
\hline Abstrak \\
\hline Tujuan penelitian ini adalah untuk mengkaji kecukupan \\
peraturan perundang-undangan yang mengatur tentang \\
penyelenggaraan investasi oleh Koperasi Simpan Pinjam \\
(KSP) dan merumuskan konstruksi hukum terkait \\
penetapan suku bunga investasi oleh KSP melalui \\
peraturan Lembaga Penjamin Simpanan (LPS) tentang
\end{tabular}




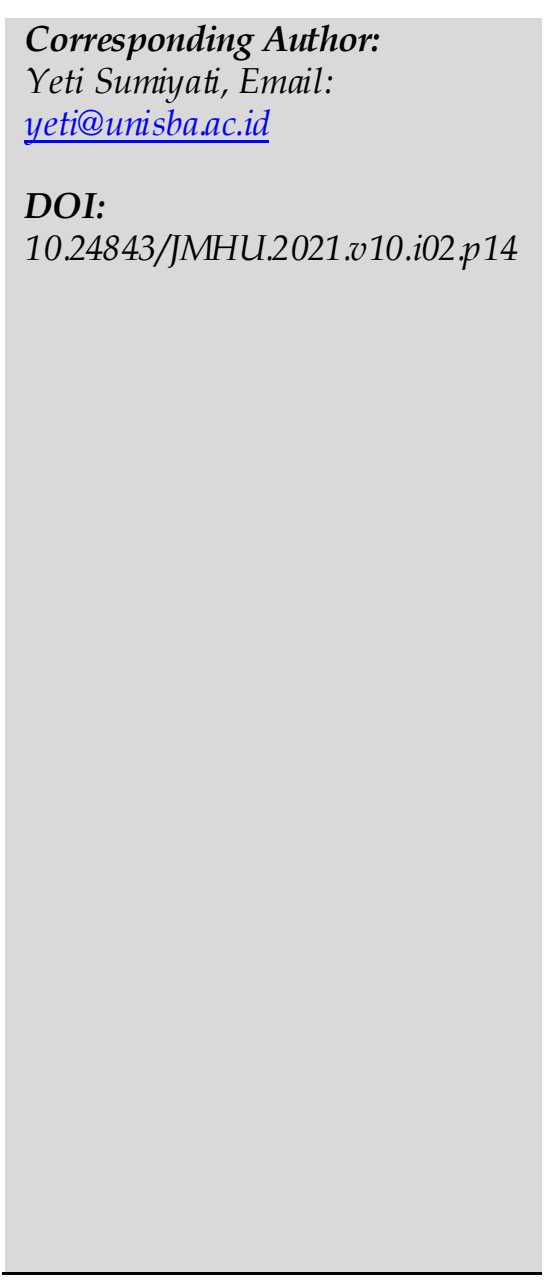

\begin{abstract}
Penetapan Tingkat Bunga Penjaminan Simpanan dalam bentuk Surat Edaran LSP. Metode penelitian menggunakan pendekatan yuridis normatif, spesifikasi penelitian deskriptif analitis dan metode analisis data yang digunakan adalah penafsiran sistematis dan konstruksi hukum analogi. Hasil penelitian menunjukkan bahwa peraturan perundang-undangan yang mengatur mengenai investasi yang dilakukan KSP tidak cukup memadai khususnya pada bagian yang berkaitan dengan penetapan suku bunga investasi sehingga masih banyak KSP yang menetapkan bunga tinggi dalam program investasinya. Undang-Undang Nomor 11 Tahun 2020 tentang Cipta Kerja dan Peraturan Pemerintah Nomor 7 Tahun 2021 tentang Kemudahan, Perlindungan dan Pemberdayaan Koperasi dan Usaha Mikro Kecil dan Menengah, juga tidak mengakomodasi ketentuan tentang program investasi yang dapat dilakukan KSP. Beberapa ketentuan baru dalam kedua peraturan tersebut dikhawatirkan memunculkan banyak praktik investasi berbunga tinggi oleh KSP yang lebih mengutamakan kepentingan lembaganya dibandingkan kesejahteraan anggota. Melalui analisis konstruksi hukum, ditemukan bahwa Surat Edaran Lembaga Penjamin Simpanan (LPS) tentang Penetapan Tingkat Bunga Penjaminan Simpanan pada Bank Umum dan Bank Perkreditan Rakyat dapat dijadikan rujukan oleh Kementerian Koperasi dan UKM untuk mendorong KSP dalam menetapkan suku bunga investasi secara wajar
\end{abstract}

\section{Pendahuluan}

Pandemi Covid-19 menguak tabir aktivitas bisnis Koperasi Simpan Pinjam (KSP) di Indonesia. Aktivitas bisnis yang dilakukan bergerak di bidang investasi dan menjanjikan bunga di atas kewajaran. KSP berorientasi pada keuntungan organisasinya daripada anggotanya sehingga pinjaman disalurkan kepada nonanggota. ${ }^{1}$ Banyak terjadi penipuan investasi berkedok KSP. ${ }^{2}$ Tercatat pada periode Februari-September 2020 terdapat 11 KSP yang dimohonkan Penundaan Kewajiban Pembayaran Utang (PKPU) ke Pengadilan Negeri Jakarta Pusat, dan terdapat 5 KSP tersebar di Pengadilan Negeri Semarang dan Surabaya.

Jumlah KSP yang diajukan PKPU ini tergolong besar untuk ukuran koperasi karena seharusnya mekanisme permasalahan keuangan diselesaikan secara musyawarah mufakat dalam Rapat Anggota (RAT). ${ }^{3}$ Tingginya angka KSP yang diputus PKPU

\footnotetext{
1 Widiastuti Widiastuti, “Urgensi Amandemen Undang Undang Perkoperasian," Jurnal Wacana Hukum 8, no. 1 (2009): 23542. hlm.70.

2 Emral Firdiansyah, "Pemahaman Masyarakat Soal Koperasi Simpan Pinjam Masih Minim," accessed August 8, 2020, https://investor.id/finance/pemahaman-masyarakat-soal-koperasisimpan-pinjam-masih-minim.

${ }^{3}$ Maizal Walfajri and Herlina Kartika Dewi, "PKPU Koperasi Bertambah, Begini Penjelasan Kemenkop UKM - Page All," accessed September 3, 2020,
} 
karena tidak mampu bertahan diterpa gelombang Pandemi Covid-19. Kasus gagal bayar yang dialami KSP terhadap para anggota atau kreditornya disebabkan antara lain terjadinya penarikan simpanan secara besar-besaran oleh anggotanya, menurunnya likuiditas koperasi karena beberapa usaha yang dijalankan KSP yang bergerak di bidang perhotelan, properti dan pariwisata terkendala kebijakan pembatasan sosial, mengandalkan dana dari nasabah, klien, anggota baru serupa dengan mekanisme ponzi, kemampuan anggota peminjam tidak berjalan normal serta bisnis yang dijalankan melalui anak usaha KSP pun terdampak.

Tidak semua KSP yang ada di Indonesia "kebablasan" sebagai usaha bersama berasaskan kekeluargaan. Namun tidak sedikit KSP berorientasi kebalikannya, dan bahkan kecenderungannya ada KSP yang menarik dana dari masyarakat non-anggota seperti shadow banking. ${ }^{4}$ Padahal, berbagai upaya dilakukan melalui serangkaian regulasi untuk mengatur aktivitas bisnis KSP termasuk kegiatan investasi dalam hal KSP memiliki kelebihan dana dan pelayanan. Permasalahannya, tidak ada satu ketentuan pun yang mengatur bagaimana mekanisme dan penetapan suku bunga investasi yang harus ditetapkan KSP, permasalahan mana menjadi semacam gunung es yang tiada berujung sampai pada satu titik KSP tidak mampu membayar bunga dan bahkan utang pokoknya kepada banyak anggota bahkan non-anggota yang berinvestasi pada KSP dengan jumlah kerugian yang besar.

Ketentuan investasi oleh KSP juga tidak diakomodasi dalam Undang-Undang Nomor 11 Tahun 2020 tentang Cipta Kerja. Kalaupun ada aturan tentang koperasi, namun tidak secara spesifik mengatur investasi yang terdapat dalam Pasal 86 UU Cipta Kerja, bahwa Koperasi Primer dibentuk paling sedikit 9 orang dari ketentuan awalnya minimal 20 orang. Ketentuan ini dikhawatirkan melahirkan embrio koperasi termasuk KSP yang jauh dari asas kekeluargaan. Berdasarkan uraian tersebut, artikel hasil penelitian ini urgen untuk memahami seberapa lengkap kebijakan KSP sebagai entitas pelaku ekonomi dalam melakukan investasi dan bagaimana mengkontruksi hukum terkait penetapan suku bunga investasi oleh KSP melalui peraturan Lembaga Penjamin Simpanan (LPS) mengenai penetapan tingkat bunga penjaminan simpanan.

Isu yang diangkat dalam artikel ini relatif baru apabila dibandingkan dengan artikel terdahulu yang sama-sama mengkaji tentang KSP. Hal ini bisa dilihat dari artikel I. Gede Hartadi Kurniawan Kurniawan (2013) lebih menekankan pada tindakan Koperasi Simpan Pinjam yang mengakibatkan Perbuatan Tindak Pidana. ${ }^{5}$ Selain itu, artikel Dessy Lina Oktaviani Suendra (2015) juga lebih menekankan pada pertanggungjawaban pidana koperasi dalam tindak pidana yang melakukan kegiatan perbankan tanpa Ijin. ${ }^{6}$ Lebih lanjut artikel tentang KSP juga diterbitkan oleh Widiastuti

https://keuangan.kontan.co.id/news/pkpu-koperasi-bertambah-begini-penjelasan-

kemenkop-ukm?page=all.

${ }^{4}$ Ferrika Sari and Khomarul Hidayat, "Kementerian Koperasi Minta Masyarakat Waspadai Praktik Shadow Banking Di Koperasi," accessed June 6, 2020, https://keuangan.kontan.co.id/news/kementerian-koperasi-minta-masyarakat-waspadaipraktik-shadow-banking-di-koperasi.

5 I Gede Hartadi Kurniawan, "Tindakan Koperasi Simpan Pinjam Yan Mengakibatkan Perbuatan Tindak Pidana," Lex Jurnalica 10, no. 1 (2013): 18070.

${ }^{6}$ Dessy Lina Oktaviani Suendra, "Pertanggungiawaban Pidana Koperasi Dalam Tindak Pidana Melakukan Kegiatan Perbankan Tanpa Ijin," Jurnal Magister Hukum Udayana 4, no. 2 (n.d.): 44152 . 
(2009) yang lebih menekankan pada urgensi amandemen Undang-Undang Perkoperasian. ${ }^{7}$ Dalam artikel ini dikaji secara spesifik kecukupan peraturan perundang-undangan yang mengatur tentang investasi oleh KSP.

Oleh karena ini permasalahan yang hendak diteliti dalam penelitian ini adalah 1) Bagaimana peraturan perundang-undangan mengatur tentang program investasi yang dilakukan KSP? dan 2) Bagaimana konstruksi hukum terkait program investasi berbunga tinggi oleh KSP melalui Surat Edaran LSP mengenai penetapan tingkat bunga penjaminan simpanan?

\section{Metode Penelitian}

Metode pendekatan penelitian yang digunakan adalah yuridis normatif, dengan mengkaji kecukupan aturan tentang investasi yang dilakukan KSP melalui penelusuran pustaka sebagai metode pengumpulan data sekunder. Ketentuan KSP di negara lain juga akan dirujuk sebagai pembanding. Spesifikasi penelitian adalah deskriptif analisis dengan memaparkan permasalahan KSP dalam menetapkan bunga tinggi pada program investasinya untuk kemudian dianalisis. Teknik analisis data untuk perumusan masalah pertama menggunakan metode penafsiran sistematis yaitu menafsirkan undang-undang sebagai bagian dari keseluruhan sistem perundangundangan dengan jalan menghubungkannya dengan undang-undang lain.8 Selain itu juga menggunakan metode analisis konstruksi hukum analogi yaitu suatu peristiwa khusus dijadikan umum yang tidak tertulis dalam undang-undang dan disimpulkan dari ketentuan yang umum itu peristiwa yang khusus, 9 untuk menganalisis permasalahan kedua. Dalam artikel ini akan digunakan ketentuan khusus berupa Surat Edaran LPS tentang penetapan bunga simpanan untuk dapat merumuskan besaran bunga investasi yang ditetapkan KSP.

\section{Hasil dan Pembahasan}

\subsection{Koperasi Simpan Pinjam dalam Kerangka Filosofis}

Fungsi Koperasi sebagai alat untuk mendemokratisasikan sumber-sumber kemakmuran bersama dan menggerakkan potensi ekonomi rakyat di pedesaan. 10 Dalam Koperasi, kepentingan pribadi dan kelompok tergabung melalui usaha bersama dan menjadi alat ampuh bagi pembangunan. ${ }^{11}$

Menurut Undang-Undang Nomor 25 Tahun 1992 tentang Perkoperasian, Koperasi melandaskan kegiatannya berdasarkan prinsip Koperasi, merupakan gerakan ekonomi rakyat, dan berasaskan kekeluargaan. Koperasi dapat menghimpun dana dan menyalurkannya melalui kegiatan usaha simpan pinjam dari dan untuk anggota Koperasi yang bersangkutan dan Koperasi lain dan/atau anggotanya. Dalam

\footnotetext{
7 Widiastuti, “Urgensi Amandemen Undang Undang Perkoperasian."

${ }^{8}$ Sudikno Mertokusumo, Mengenal Hukum; Suatu Pengantar (Yogyakarta: Liberty, 2007) hlm. 157;

Sudikno Mertokusumo, Penemuan Hukum: Sebuah Pengantar (Yogyakarta: Liberty, 2009). hlm. 67

${ }_{9}^{9}$ Mertokusumo, Mengenal Hukum; Suatu Pengantar. hlm. 161.

${ }^{10}$ Jimly Asshiddiqie, "Konstitusi Ekonomi” (Penerbit buku Kompas, Jakarta, 2010).

${ }^{11}$ Sartika Partomo, Ekonomi Koperasi (Bogor: Ghalia Indonesia, 2009).
} 
Penjelasan Peraturan Pemerintah Nomor 9 Tahun 1995 Tentang Pelaksanaan Kegiatan Usaha Simpan Pinjam oleh Koperasi, kegiatan usaha simpan pinjam ini sangat dibutuhkan oleh para anggota koperasi dan banyak manfaat dalam rangka meningkatkan modal usaha para anggotanya. Dalam menjalankan usahanya, KSP wajib memperhatikan aspek permodalan, likuiditas, solvabilitas dan rentabilitas guna menjaga kesehatan usaha dan menjaga kepentingan semua pihak yang terkait. Kesejahteraan yang sebesar-besarnya menjadi tujuan utama pengembangan KSP.

KSP berkembang di negara-negara Eropa Barat dan Timur pada awal tahun 1900-an. Pendirian KSP memiliki prinsip menolong diri, sumber utama kredit bagi rumah tangga, perusahaan kecil dan menengah, dan prinsip-prinsip khas Koperasi yang ditetapkan para pionir. ${ }^{12}$ KSP di Cyprus dikenal dengan Koperasi Antroposentris, memainkan peran penting baik dalam pembangunan ekonomi dan sosial serta menyediakan pembiayaan jangka pendek dan panjang untuk tujuan pertanian. ${ }^{13}$ Sifat kooperatif sistem koperasi Jerman telah mampu melayani pasar dan anggotanya secara memadai. ${ }^{14}$ Menurut hukum Yunani, sistem koperasi kredit dibedakan antara koperasi bank dan koperasi kredit. Bank koperasi adalah lembaga perbankan, sedangkan koperasi kredit bukan lembaga perbankan dan tidak dapat menawarkan layanan perbankan dengan tujuan mengakomodasi kaum yang tidak terjamah oleh pembiayaan perbankan. ${ }^{15}$

Koperasi di Botswana berpotensi sebagai katalisator untuk pembangunan berkelanjutan, khususnya KSP yang telah terbukti menjadi saluran peningkatan akses keuangan bagi masyarakat yang secara tradisional tidak memiliki akses kepada sektor perbankan. Namun demikian, bukan berarti tidak ada koperasi yang tidak memiliki kemandirian secara ekonomi dan bebas dari terpaan krisis. Hanya KSP yang memiliki komite manajemen yang terampil, artikulasi yang jelas dari dan kepatuhan terhadap kebijakan kredit, adanya budaya menabung di wilayah operasi, tata kelola perusahaan yang baik, tarif kredit yang ditetapkan, nomor keanggotaan, dan tingkat anggota literasi keuangan yang tangguh yang mampu bertahan dan berperan dalam pembangunan berkelanjutan.16

Koperasi keberadaannya sangat vital karena merupakan lembaga yang secara timbal balik sebagai usaha bersama dalam keanggotaannya. Koperasi adalah perwujudan dari materialisasi dan ekspresi ekonomi naluri manusia yang sangat spesifik memiliki

12 Johann Brazda, Holger Blisse, and Robert Schediwv, "Cooperative Banks in the Austrian Banking System," in Credit Cooperative Institutions in European Countries (Springer, 2016), 3-18; Donal McKillop et al., "Cooperative Financial Institutions: A Review of the Literature," International Review of Financial Analysis 71 (2020): 101520; Gregor Rabong and Stefan Radakovics, "The Uniform Co-Operative Value Core-Evidence from Austria," Journal of CoOperative Organization and Management 8, no. 2 (2020): 100118.

${ }^{13}$ Akis Kleanthous and Athanasios Hadjimanolis, "Co-Operative Credit Institutions in Cyprus," in Credit Cooperative Institutions in European Countries (Springer, 2016), 19-41.

${ }^{14}$ Massimo Biasin, "The German Cooperative Banks. An Economic Overview," in Credit Cooperative Institutions in European Countries (Springer, 2016), 83-110.

${ }^{15}$ Simeon Karafolas, "The Greek Cooperative Credit System," in Credit Cooperative Institutions in European Countries (Springer, 2016), 111-26.

${ }^{16}$ Laone Gosego Nthaga, "An Analysis of the Profitability and Sustainability of Savings and Credit Co-Operatives in Botswana" (University of Cape Town, 2018). 
ikatan sosial. ${ }^{17}$ Koperasi dapat mengembangkan pembangunan inklusif dengan segala tantangannya, melalui platform yang secara aktif mengedepankan musyawarah dan partisipasi masyarakat berpenghasilan rendah dan kurang beruntung. Diperlukan pengawasan pemerintah dan tata kelola koperasi agar koperasi tetap menjalankan perannya secara berkelanjutan. 18

\subsection{Peraturan Perundang-Undangan tentang Program Investasi yang Dilakukan Koperasi Simpan Pinjam}

Penafsiran sistematis akan menjadi metode analisis data yang digunakan untuk mengkaji kelengkapan peraturan perundang-undangan yang mengatur tentang program investasi oleh KSP. Merujuk pada penafsiran sistematis maka satu pasal dengan pasal lain dalam satu undang-undang akan dihubungkan dengan satu pasal dengan pasal lain dari undang-undang yang berbeda agar ditetapkan suatu rumusan tentang kecukupan peraturan perundang-undangan di bidang perkoperasian mengatur tentang investasi yang dilakukan KSP.

Peraturan perundang-undangan di bidang KSP terdiri dari: UU Perkoperasian, PP tentang Pelaksanaan Kegiatan Usaha Simpan Pinjam oleh Koperasi, Permen KUKM tentang Usaha Simpan Pinjam oleh Koperasi. Selain dengan peraturan perundangundangan tersebut, UU Cipta Kerja dan Peraturan Pemerintah Nomor 7 Tahun 2021 tentang Kemudahan, Perlindungan dan Pemberdayaan Koperasi dan Usaha Mikro Kecil dan Menengah, dianalisis juga untuk tercapai satu simpulan bahwa peraturan perundang-undangan di bidang koperasi telah cukup memadai atau tidak, mengatur tentang program investasi yang dilakukan KSP.

Pada UU Perkoperasian diatur tentang KSP sebagai salah satu kegiatan koperasi, namun ketentuan secara jelas mengenai KSP diamanatkan oleh UU Perkoperasian diatur lebih lanjut dalam PP tentang Pelaksanaan Kegiatan Usaha Simpan Pinjam oleh Koperasi. Artinya, ketentuan KSP dalam UU Perkoperasian ini hanya diatur dalam satu pasal saja yaitu Pasal 44 UU Perkoperasian yang menyebutkan istilah kegiatan usaha simpan pinjam sebagai salah satu kegiatan dalam koperasi.

Pada PP tentang Pelaksanaan Kegiatan Usaha Simpan Pinjam oleh Koperasi disebutkan bahwa kegiatan usaha simpan pinjam bisa dilaksanakan oleh KSP, dimana kegiatannya hanya usaha simpan pinjam, dan oleh Unit Simpan Pinjam, sebagai sebagai bagian dari kegiatan usaha Koperasi yang bersangkutan. Pada Pasal 3-7 PP tentang Pelaksanaan Kegiatan Usaha Simpan Pinjam oleh Koperasi mengatur tentang Pendirian KSP. Dimulai dari Pasal 8-15 PP tentang Pelaksanaan Kegiatan Usaha Simpan Pinjam oleh Koperasi pada intinya mengatur tentang Pengelolaan KSP, bahwa pengelolaan koperasi dilakukan oleh pengurus dengan kriteria yang telah ditetapkan. Pengelola diwajibkan memiliki keahlian di bidang keuangan atau pernah mengikuti pelatihan di bidang simpan pinjam atau magang dalam usaha simpan pinjam dan terhindar dari konflik kepentingan. Perolehan keuntungan KSP digunakan berupa sisa hasil usaha dipergunakan untuk semata-mata kesejahteraan anggota dan

17 John Restakis, Humanizing the Economy: Co-Operatives in the Age of Capital (New Society Publishers, 2010).

18 Alexander Borda-Rodriguez and Hazel Johnson, "Inclusive Development and Co-Operatives," European Journal of Development Research 32, no. 4 (September 1, 2020): 976-97, https://doi.org/10.1057/S41287-019-00249-9. 
pengembangan koperasi. Pengelolaan KSP wajib memperhatikan aspek permodalan, likuiditas solvabilitas dan rentabilitas guna menjaga kesehatan usaha dan menjaga kepentingan semua pihak yang terkait.

Berkaitan dengan kegiatan usaha dan modal yang diatur Pasal 14-22 PP tentang Pelaksanaan Kegiatan Usaha Simpan Pinjam oleh Koperasi, KSP wajib menyediakan modal sendiri dan dapat ditambah dengan modal penyertaan. Jumlah modal sendiri tidak boleh berkurang dari jumlah semula. Selain modal sendiri dan modal penyertaan, KSP dapat menghimpun modal pinjaman. Dalam menjalankan usahanya menghimpun dana dan/atau modal pinjaman, modal penyertaan serta menyalurkannya melalui kegiatan usaha simpan pinjam dari dan untuk anggota koperasi yang bersangkutan, calon anggota koperasi yang bersangkutan, koperasi lain dan atau anggotanya, KSP harus mendasarkan pada kemampuannya untuk membayar kembali. Dalam ketentuan tersebut juga jelas dibatasi siapa saja yang dapat menyimpan/ menginvestasikan dananya pada KSP dan tidak dibuka untuk anggota lain secara bebas.

Inti dari ketentuan pasal-pasal tersebut adalah, bahwa dalam menghimpun modal pinjaman dan modal penyertaan koperasi wajib memperhitungkan terlebih dahulu kemampuannya untuk dapat memenuhi kewajiban jangka pendek dan jangka panjang berdasarkan kekayaan yang dimiliki, agar koperasi tersebut dapat melaksanakan kegiatan usahanya dan tetap dipercaya. Penjelasan pasal 14 PP tentang Pelaksanaan Kegiatan Usaha Simpan Pinjam oleh Koperasi ini menjadi penting dalam menyikapi praktik investasi bunga tinggi yang ditetapkan KSP. Seharusnya feasibility study telah dilakukan pengurus KSP sebelum launching produk investasinya, sebagai bukti bahwa KSP sudah memiliki semacam self assessment bahwa dia layak untuk menawarkan program investasi.

Dalam hal terdapat kelebihan dana yang telah dihimpun, setelah melaksanakan kegiatan pemberian pinjaman, maka KSP dapat menempatkan dana dalam bentuk giro, deposito berjangka, tabungan, sertifikat deposito pada bank dan lembaga keuangan lainnya, pembelian saham melalui pasar modal, dan mengembangkan dana tabungan melalui sarana investasi lainnya.Secara keseluruhan PP tentang Pelaksanaan kegiatan usaha simpan pinjam, mengatur tentang kegiatan usaha koperasi melalui program menghimpun dana yang selama ini dikenal dengan istilah investasi. Namun demikian, tidak diatur secara spesifik kegiatan investasi seperti apa yang harus dilaksanakan oleh KSP.

Hal yang sama juga diatur dalam PermenKUKM tentang Usaha Simpan Pinjam oleh Koperasi. Dalam permen tersebut juga hanya mengatur mengenai kegiatan investasi pada 1 pasal saja yaitu Pasal 22, bahwa kegiatan menghimpun dana dalam bentuk simpanan dan tabungan. Pemberian nama produk simpanan koperasi merupakan wewenang pengurus. Simpanan diberikan imbalan jasa dalam bentuk bunga yang besarnya ditetapkan Rapat Anggota (RAT), dan KSP wajib menjamin keamanan simpanan dan tabungan anggota, calon anggota, koperasi lain dan atau anggotanya. Ketentuan tersebut hanya menetapkan bahwa imbalan jasa simpanan dalam hal ini investasi berupa bunga yang ditetapkan oleh RAT.

Sayangnya, terkait dengan investasi tersebut tidak diiringi dengan batasan penetapan suku bunga dari kegiatan investasi tersebut. Ketiadaan pengaturan secara tegas mengenai penetapan suku bunga pada program investasi yang paling tidak 
seharusnya disesuaikan dengan kepatutan dan kewajaran, menimbulkan beragam program investasi dalam praktik yang dilakukan KSP dengan bunga yang diatas kepatutan dan kewajaran.

Merujuk pada ketiga peraturan perundang-undangan tentang koperasi dalam UU Perkoperasian, PP tentang Pelaksanaan Kegiatan Usaha Simpan Pinjam dan PermenKUKM tentang Usaha Simpan Pinjam oleh Koperasi, maka KSP diperkenankan untuk menyelenggarakan kegiatan investasi melalui berbagai bentuk, hanya saja tidak diiringi dengan penetapan dan pembatasan bunga dari program investasi tersebut. Penting kiranya ketiga ketentuan tersebut dihubungkan dengan peraturan perundangundangan terbaru. Peraturan tersebut adalah UU Cipta Kerja dan PP tentang Kemudahan, Perlindungan dan Pemberdayaan Koperasi dan Usaha Mikro Kecil dan Menengah.

Pada Pasal 86 UU Cipta Kerja ditegaskan, bahwa dalam rangka memberikan kemudahan, perlindungan, dan pemberdayaan koperasi dan UKM, maka beberapa ketentuan UU Perkoperasian diubah dan dihapuskan atau ditetapkan peraturan yang baru. Tidak ada 1 pasal pun dalam UU Cipta Kerja yang berkaitan dengan koperasi, mengatur tentang program investasi. Dalam UU Cipta Kerja, selain jumlah anggota dalam koperasi primer, ketentuan yangg signifikan diatur adalah bahwa pelaksanaan rapat anggota dapat dilakukan secara daring dan luring. Lebih lanjut juga diatur tentang usaha koperasi sebagai usaha yang berkaitan langsung dengan kepentingan anggota untuk meningkatkan anggota dan kesejahteraan anggota juga non-anggota.

Pasal 86 UU Cipta Kerja yang mengubah Pasal 6 UU Perkoperasian menyatakan, bahwa koperasi primer dibentuk paling sedikit oleh 9 orang. Ketentuan ini memunculkan kekhawatiran menjadi ajang munculnya KSP yang jauh dari ruh konstitusional dan menguntungkan diri personal pendirinya karena menetapkan jumlah anggota Koperasi menjadi minimal 9 orang.

Widiastuti dalam artikelnya menyatakan, bahwa secara empiris banyak KSP yang sengaja tidak menambah anggota manakala dari anggota koperasi yang minimal 20 orang keluar atau meninggal, dengan tujuan untuk memperbesar keuntungan bagi pengurus. Selain itu, banyak anggota fiktif dalam akta pendirian KSP semata-mata hanya dalam rangka pemenuhan persyaratan dalam akta pendirian. ${ }^{19}$ Artinya, ketika masih diatur dalam UU Perkoperasian yang mengatur jumlah minimal anggota koperasi primer saja, banyak terjadi penyelewengan untuk secara sengaja mengurangi jumlah anggota, apalagi dengan diaturnya dalam UU Cipta Kerja menjadi minimal 9 orang. Dikhawatirkan tujuan menguntungkan pengurus dan organisasinya dan tidak untuk sebesar-besarnya kepentingan anggota akan semakin terwujud, padahal praktik penyimpangan berupa investasi berkedok KSP banyak terjadi.

Pada Pasal 86 UU Cipta Kerja yang mengubah Pasal 43 Ayat (3) UU Perkoperasian dijelaskan bahwa, apabila terdapat kelebihan kemampuan pelayanan koperasi, maka dapat digunakan untuk memenuhi kebutuhan masyarakat yang bukan anggota koperasi dalam rangka menarik masyarakat menjadi anggota koperasi. Ketentuan tersebut dapat diartikan, baik pelayanan dalam menghimpun dana maupun menyalurkannya melalui kegiatan simpan pinjam, dibuka juga bagi non-anggota dan dikhawatirkan akan semakin melegalkan penyimpangan aktivitas koperasi menghimpun dana dari masyarakat atau praktik shadow banking seperti yang

${ }^{19}$ Widiastuti, “Urgensi Amandemen Undang Undang Perkoperasian." 
dilakukan KSP Indosurya Cipta, KSP Hanson, 20 dan KSP lain yang diperkirakan sama yaitu menyelenggarakan investasi dengan bunga tinggi kepada non-anggota yang dilakukan KSP Koperasi BMT CSI Syariah Sejahtera dan KSPPS BMT CSI Madani Nusantara Kota Cirebon, dan KSP Pracico. ${ }^{21}$

Pendapat yang sama disampaikan I Gede Hartadi Kurniawan dalam artikelnya, bahwa KSP banyak ditengarai melakukan praktek perbankan yang jelas-jelas melanggar Pasal 1 ayat 2 Undang-Undang Nomor 10 Tahun 1998 tentang Perbankan yang menerangkan bahwa hanya institusi perbankan yang diperbolehkan untuk menyimpan dana pihak ketiga dan menyalurkan kredit ke masyarakat. Pelanggaran terjadi karena KSP yang menyimpan dana bukan dari anggota dan juga menyalurkannya ke bukan anggota. ${ }^{22}$ Alih-alih dibuat peraturan yang mengatur sanksi bagi KSP yang menyimpang, UU Cipta Kerja malah membuka peluang KSP melakukan kegiatan pelayanan kepada nonanggota.

Kekhawatiran yang sama juga sempat disampaikan Widiastuti dalam artikelnya terkait meningkatnya KSP yang lebih beorientasi pada keuntungan bagi lembaganya yang jamak terjadi di masyarakat, karena dengan menawarkan uangnya (pinjaman) pada pihak ketiga yang non-anggota maka keuntungan yang diperoleh tidak harus dikembalikan kepada anggota, karena SHU sebagai bagian keuntungan perusahaan yang dibagikan kepada anggota didasarkan jasa yang telah diberikan anggota yang bersangkutan kepada koperasi. KSP cenderung menjadi lembaga yang yang sematamata mencari keuntungan daripada meningkatkan kesejahteraan anggotanya. ${ }^{23}$

UU Cipta Kerja seolah menghidupkan kembali ruh Undang-Undang Nomor 17 Tahun 2012 tentang Perkoperasian yang telah dicabut oleh Mahkamah Konstitusi. Perlu dipahami, bahwa pada Tahun 2012 pernah diundangkan produk hukum perkoperasian. Namun, karena UU 17 Tahun 2012 mengutamakan skema permodalan materiil, finansial, dan mengesampingkan modal sosial yang menjadi ciri fundamental Koperasi sebagai suatu entitas khas pelaku ekonomi berdasarkan Pancasila dan UUD 1945, maka MK membatalkan UU tersebut. 24 Konsekuensi hukumnya, UU Perkoperasian tentang Perkoperasian kembali berlaku. Namun dalam praktiknya banyak KSP yang mengutamakan skema permodalan materiil dan finansial seperti yang diatur dalam UU yang telah dibatalkan MK. Dengan dihapuskannya beberapa

\footnotetext{
${ }^{20}$ Ferrika Sari and Khomarul Hidayat, "Kementerian Koperasi Minta Masyarakat Waspadai Praktik Shadow Banking Di Koperasi."

${ }^{21}$ Redaksi, "Kreditur Setujui Proposal Perdamaian Debitur KSP Pracico Inti Sejahtera Dalam Proses PKPU Sementara | Vonisinvestigasi.Co.Id," https://www.vonisinvestigasi.co.id/2021/01/12/kreditur-setujui-proposal-perdamaiandebitur-ksp-pracico-inti-sejahtera-dalam-proses-pkpu-sementara/.

${ }^{22}$ Kurniawan, "Tindakan Koperasi Simpan Pinjam Yan Mengakibatkan Perbuatan Tindak Pidana"; Oktaviani Suendra, "Pertanggungjawaban Pidana Koperasi Dalam Tindak Pidana Melakukan Kegiatan Perbankan Tanpa Ijin."

${ }^{23}$ Widiastuti, “Urgensi Amandemen Undang Undang Perkoperasian.” hlm. 66.

${ }^{24}$ Anonymous, "MK Batalkan Undang-Undang Tentang Perkoperasian - ANTARA News," n.d., https:/ / www antaranews.com/berita/436287/mk-batalkan-undang-undang-tentang-

perkoperasian; Sastrawidjaja Man S, “Beberapa Perubahan Undang-Undang Nomor 17 Tahun 2012 Tentang Perkoperasian," in Peran Hukum Dalam Pembangunan Di Indonesia: Kenyataan, Harapan, Dan Tantangan, Liber Amicorum Prof. Dr. Etty R. Agoes, SH., LL.M, (Bandung: Remaja Rosdakarya, 2013). hlm. 602.
} 
pasal dalam UU Perkoperasian melalui UU Cipta Kerja dikhawatirkan semakin banyak praktik investasi yang dilakukan KSP berbunga tinggi.

Ketentuan Pasal 86, Pasal 87, Pasal 88, Pasal 89, Pasal 90, Pasal 91, Pasal 94, Pasal 104, dan Pasal 185 huruf b UU Cipta Kerja, diatur lebih lanjut dalam PP tentang Kemudahan, Pelindungan, dan Pemberdayaan Koperasi dan Usaha Mikro, Kecil, dan Menengah. Ketentuan yang secara khusus mengatur tentang KSP dalam PP tentang Kemudahan, Pelindungan, dan Pemberdayaan Koperasi dan Usaha Mikro, Kecil, dan Menengah terdapat pada Pasal 9 yang mewajibkan KSP menyampaikan laporan secara periodik dan sewaktu-waktu kepada kementerian dan atau dinas yang disampaikan melalui sistem pelaporan secara elektronik. Apabila sistem pelaporan secara elektronik belum terbentuk maka koperasi menyampaikan laporan secara manual. Pasal 15-18 PP tentang Kemudahan, Pelindungan, dan Pemberdayaan Koperasi dan Usaha Mikro, Kecil, dan Menengah yang pada intinya mengatur tentang KSP dan pembiayaan syariah dibuka kesempatan untuk melaksanakan kegiatan usahanya secara elektronik. Selain itu, pada koperasi syariah diwajibkan memiliki dewan pengawas syariah yang tugas dan kewenangannya memberikan nasihat dan saran kepada pengurus serta mengawasi kegiatan koperasi.

Masa pandemi covid-19 ini dapat dikategorikan dalam kondisi darurat tertentu sebagaimana yang ditetapkan dalam Pasal 20 PP tentang Kemudahan, Pelindungan, dan Pemberdayaan Koperasi dan Usaha Mikro, Kecil, dan Menengah, sehingga koperasi termasuk di dalamnya KSP mendapatkan perlindungan dari pemerintah pusat dan pemerintah daerah melalui pemulihan usaha koperasi yang terdiri dari:
a. Restrukturisasi kredit
b. Rekonstruksi usaha
c. Bantuan modal
d. Bantuan bentuk lain

Secara keseluruhan pada PP tentang Kemudahan, Pelindungan, dan Pemberdayaan Koperasi dan Usaha Mikro, Kecil, dan Menengah tidak mengatur tentang kegiatan investasi yang dapat dilakukan oleh KSP sehingga dalam ketentuan UU Cipta Kerja dan peraturan pelaksananya belum mengakomodasi pihak yang berkepentingan dalam kegiatan bisnis investasi KSP. Padahal, di dalam praktik banyak dilakukan kegiatan investasi oleh KSP yang menimbulkan banyak kerugian bagi anggota, mitra, kreditur dan nasabah.

Di negara lain juga terdapat peraturan tentang baik koperasi secara umum maupun KSP atau savings and credit co-operatives. Di China berkembanganya koperasi dengan baik karena tidak terlepas dari keinginan politik pemerintahnya yang kuat untuk mempunyai lembaga keuangan yang akan membantu masyarakat yang berpendapatan rendah utamanya adalah masyarakat petani. Keberhasilan koperasi didukung oleh "political will" pemerintah. Pemerintah ingin memajukan kesejahteraan masyarakat yang berbasiskan kekeluargaan. Di China dimana pemerintahannya komunis segala kebijakan diatur tegas, masyarakat tidak mempunyai akses untuk ikut menetapkan kebijakan/ kajian kemana arah perkembangan ekonomi sehingga dengan adanya kemampuan menetapkan sendiri dari pemerintah dan juga memberikan strategi ekonomi yang nanti akan diarahkan kepada ekonomi berbasis masyarakat, 
tujuan dari keberadaan koperasi berhasil. ${ }^{25}$ Saat ini, tidak ada koperasi kredit di Slovakia karena tidak ada undang-undang yang memperbolehkan keberadaan mereka. Undang-Undang Bank tidak mengizinkan operasi koperasi kredit karena hanya memungkinkan bank dalam bentuk perusahaan saham gabungan. Namun ada rancangan 'Undang-undang tentang savings and credit co-operatives', yang disusun oleh para ahli di bidang hukum dan koperasi serta oleh AXA perusahaan di Bratislava (ibu kota Slovakia) yang berorientasi menuju pengembangan, proyeksi dan penyediaan sistem informasi bank.26

Pada tahun 1996 dibentuklah Undang-Undang tentang Koperasi (The Federal Law on Co-operatives (1996) di Serbia. Undang-Undang tentang Koperasi (1996) menyatakan bahwa petani dapat membentuk koperasi simpan pinjam, dan koperasi pertanian dapat menyediakan unit simpan pinjam untuk kebutuhan anggota mereka. Oleh karena itu, koperasi pertanian difungsikan untuk membentuk layanan simpan pinjam sebagai bagian dari koperasi. Namun, dalam ketentuan Pasal 2 Undang-Undang federal tentang Koperasi (1996) dinyatakan bahwa, koperasi dapat berbentuk koperasi simpan pinjam, but that upon their foundation their "... organisation, work and management are subject to the provisions of the federal law that regulates banks and other financial organisations. Artinya, merujuk pada UU Koperasi Serbia tahun 1996, koperasi simpan pinjam yang didirikan harus tunduk pada The Federal Law on Co-operatives (1996), baik organisasinya, lingkup usahanya, dan manajemennya. 27 Pada Tahun 2008 Kenya memberlakukan Undang-Undang Masyarakat Savings And Credit Co-Operative (SACCO). UU Masyarakat SACCO ini membentuk Societies Regulatory Authority (SASRA) Badan Pemerintah Semi-Otonom yang berada di bawah kementerian lini dan ditugasi untuk bertanggung jawab atas perizinan dan pengawasan pengambilan simpanan masyarakat SACCO di Kenya. Regulator memiliki peran untuk melakukan pengawasan dan memastikan bahwa perusahaan mematuhi pengungkapan/ keterbukaan pelaporan yang diharapkan.28

\footnotetext{
${ }^{25}$ Nicholas Loubere and Heather Xiaoquan Zhang, "Co-Operative Financial Institutions and Local Development in China," Journal of Co-Operative Organization and Management 3, no. 1 (2015): 32-39.

${ }^{26}$ Elena Súbertová, "Credit Co-Operatives in Slovakia," in Credit Cooperative Institutions in European Countries (Springer, 2016), 405-17.

27 Richard Simmons and Marija Nikolic, "Credit Co-Operatives in Serbia: Retrospect and Prospect," in Credit Cooperative Institutions in European Countries (Springer, 2016),379-404.

${ }^{28}$ Maina Waiganjo, Serah Wanyoike, and Evans Koitaba, "Effect of Compliance to Sacco Regulatory Authority (SASRA) Regulations on Financial Performance of Deposit Taking Savings and Credit Co-Operatives (SACCO) Kenya," Journal of Economics, Management and Trade, 2016, 1-6.
} 


\subsection{Konstruksi Hukum terkait Program Investasi Berbunga Tinggi Oleh KSP melalui Surat Edaran LSP mengenai Penetapan Tingkat Bunga Penjaminan Simpanan}

Aturan tentang KSP yang selama ini ada, seperti yang telah dianalisis dalam uraian sebelumnya, tidak mengatur tentang investasi. Kalaupun ada ketentuan tentang investasi, hanya sebatas kegiatan menghimpun dana atau modal pinjaman atau modal penyertaan yang imbalan jasa berupa bunga ditetapkan oleh RAT. Berkaitan dengan prosentase bunga dari program investasi yang diselenggarakan/ ditawarkan KSP kepada anggota dan masyarakat tidak ada pengaturannya sama sekali. Hal inilah yang menjadi penyebab banyaknya program investasi yang diselenggarakan KSP berbunga tinggi.

Pada KSP Koperasi BMT CSI Syariah Sejahtera dan KSPPS BMT CSI Madani Nusantara Kota Cirebon melakukan praktik pengumpulan dana masyarakat secara illegal. KSP tersebut menghimpun dana dari masyarakat melalui investasi emas dan tabungan dengan imbal hasil 5\% per bulan. ${ }^{29}$ Jumlah korban 7.000 orang dan jumlah kerugian mencapai Rp 700 miliar. ${ }^{30}$ Pada KSP Indosurya Cipta, bermula ketika dana publik yang tersimpan di KSP Indosurya Cipta mencapai Rp10 triliun dan tidak dapat dicairkan. Koperasi ini menjanjikan bunga tinggi $9 \%$ hingga $12 \%$ per tahun dalam program investasinya. Penetapan prosentase tersebut jauh di atas bunga deposito yang berkisar $5 \%$ hingga $7 \%$ pada periode yang sama. ${ }^{31}$ Pada KSP Hanson Mitra Mandiri, bunga simpanan berjangka yang didapatkan anggota untuk jangka tiga bulan adalah sebesar 10 persen, simpanan berjangka enam bulan adalah 11 persen dan untuk jangka satu tahun bunganya sebesar 12 persen. Para anggota dan non-anggota memiliki simpanan di KSP Hanson Mitra Mandiri dan pada jangka waktu pencairan dana simpanan, KSP Hanson Mitra Mandiri tidak menyiapkan sumber dana untuk pengembalian, padahal simpanan berjangka itu bisa tiga bulan atau enam bulan. ${ }^{32}$ Pada KSP Pracico Inti Utama, program yang dilakukan dengan cara menawarkan kerja sama investasi dan simpanan dengan imbalan hasil keuntungan yang tinggi, berkisar antara 10\%-12\% per tahun. Dalam pelaksanaannya, pembayaran keuntungan investasi itu tidak sesuai dengan yang dijanjikan. Bahkan lebih parahnya, dana simpanan pokok

${ }^{29}$ Thomas Mola, "Investasi Bodong Berkedok Koperasi Kian Marak - Ekonomi Bisnis.Com," accessed March 17, 2017, https:/ /ekonomi.bisnis.com/read/20170317/87/637992/investasibodong-berkedok-koperasi-kian-marak.

30 Sylke Febrina Laucereno, "Ini 12 Koperasi Abal-Abal Yang Bikin Buntung," accessed December 14, 2018, https:/ / finance.detik.com/ moneter/d-4329974/ini-12-koperasi-abal-abalyang-bikin-buntung.

31 Maizal Walfajii and Tendi Mahadi, “Tersangkut Kasus, Koperasi Indosurya Cipta Ikuti Tiga Sidang PKPU," accessed May 3, 2020, https://keuangan.kontan.coid/news/tersangkutkasus-koperasi-indosurya-cipta-ikuti-tiga-sidang-pkpu; Ferrika Sari and Yudho Winarto, "Indef Sebut Gagal Bayar Koperasi Karena Pengawasan Lemah - Page 2," accessed May 18, 2020, https://keuangan.kontan.co.id/news/indef-sebut-gagal-bayar-koperasi-karenapengawasan-lemah?page $=2$.

${ }^{32}$ Caesar Akbar and Dewi Rina Cahyani, “Kasus Gagal Bayar Koperasi Hans on, Nasabah Tolak Solusi Pengurus - Bisnis Tempo.Co," accessed January 29, 2020, https:/ / bisnis.tempo.co/read/1301212/kasus-gagal-bayar-koperasi-hanson-nasabah-tolaksolusi-pengurus; Ali Mustofa, "Analisis Hukum Kasus Hanson, Himpun Dana Masyarakat Berkedok Koperasi," accessed March 3, 2020, https://www.lawjustice.co/artikel/82238/analisis-hukum-kasus-hanson-himpun-dana-masyarakat-berkedokkoperasi/. 
yang telah disetorkan tidak dapat dicairkan. Diperkirakan total nilai kerugian nasabah dalam kasus gagal bayar ini mencapai Rp1,3 triliun. 33

Dari sebagian kasus KSP tersebut, yang harus diteliti adalah bagaimana seharusnya penetapan suku bunga simpanan atau investasi pada KSP mengingat selama ini KSP menetapkan bunga tinggi pada program investasinya. Hal ini perlu dilakukan karena ketiadaan aturan dari Kementerian KUKM tentang KSP yang menetapkan bunga tinggi dalam program investasinya. Dalam menjawab permasalahan tersebut, maka metode konstruksi hukum diterapkan dengan merujuk pada ketentuan tentang investasi yang dikeluarkan oleh LPS. Pada metode konstruksi hukum khususnya analogi, ketentuan khusus ditarik dari pikiran subjek ke ketentuan umum. Tingkat suku bunga penjaminan simpanan akan dianalogikan ke dalam bunga yang ditetapkan dalam program menghimpun dana atau investasi oleh KSP.

Kewenangan menetapkan tingkat suku bunga pada awalnya ada pada Bank Indonesia. Hal ini dapat dilihat dari Penjelasan Pasal 10 Undang-Undang Republik Indonesia Nomor 23 Tahun 1999 tentang Bank Indonesia sebagaimana telah diubah dalam Undang-Undang Republik Indonesia Nomor 3 Tahun 2004 tentang Perubahan Atas Undang-Undang Republik Indonesia Nomor 23 Tahun 1999 tentang Bank Indonesia, menyatakan bahwa yang dimaksud dengan penetapan tingkat diskonto adalah penetapan tingkat bunga tertentu yang diberlakukan oleh Bank Indonesia antara lain dalam operasi pasar terbuka dalam rangka kredit dari Bank Indonesia maupun dalam pelaksanaan fungsi lender of the last resort.

Peraturan Bank Indonesia Nomor : 7/ 11 /PBI/2005 tentang Perubahan Atas Peraturan Bank Indonesia Nomor 6/11/PBI/2004 tentang Suku Bunga Penjaminan Simpanan Pihak Ketiga dan Pasar Uang antar Bank - 31 Maret 2005 dan Peraturan Bank Indonesia Nomor : 7/28/PBI/2005 tentang Perubahan Kedua atas Peraturan Bank Indonesia Nomor 6/11/PBI/2004 tentang Suku Bunga Penjaminan Simpanan Pihak Ketiga dan Pasar Uang Antar Bank - 1 September 20052 menjadi salah satu wujud kewenangan BI menetapkan suku bunga penjaminan simpanan. Dalam Penjelasan Peraturan Bank Indonesia Nomor: 7/28/PBI/2005 tentang Perubahan Kedua atas Peraturan Bank Indonesia Nomor 6/11/PBI/2004 tentang Suku Bunga Penjaminan Simpanan Pihak Ketiga dan Pasar Uang Antar Bank, disebutkan bahwa sejak bulan Juli 2005, Bank Indonesia secara resmi menggunakan suku bunga sebagai sasaran operasional pengendalian moneter menggantikan base money. Suku bunga tersebut adalah BI Rate yang merupakan suku bunga dengan tenor satu bulan yang diumumkan oleh Bank Indonesia secara periodik yang berfungsi sebagai sinyal (stance) kebijakan moneter. Dalam rangka meningkatkan efektifitas pelaksanaan kebijakan moneter khususnya kebijakan suku bunga maka Bank Indonesia memandang perlu untuk melakukan penyesuaian terhadap dasar perhitungan penetapan maksimum suku bunga penjaminan pihak ketiga dalam Rupiah. Penyesuaian tersebut dilakukan dengan pertimbangan agar maksimum suku bunga penjaminan bergerak searah dengan BI Rate.

Namun, semenjak diundangkannya Undang-Undang Nomor 24 Tahun 2004 tentang Lembaga Penjamin Simpanan khusus Pasal 19 dan 20 dan penjelasannya, maka

\footnotetext{
33 Aries Wijaksena, "Korban Investasi Bodong Melapor Ke Polda Metro," accessed October 12, 2020, https://mediaindonesia.com/megapolitan/352194/korban-investasi-bodong-melaporke-polda-metro.
} 
kewenangan menetapkan suku bunga penjaminan simpanan beralih kepada LPS. Pada Penjelasan Pasal 19 Ayat 1 huruf b UU LPS disebutkan, bahwa nasabah penyimpan yang merupakan pihak yang diuntungkan secara tidak wajar misalnya nasabah yang memperoleh hasil bunga jauh di atas tingkat pasar. Pasal 20 UU LPS menjelaskan, bahwa:

(1) Dalam hal nasabah penyimpan sebagaimana dimaksud dalam Pasal 19 ayat (1) merasa dirugikan, maka nasabah dimaksud dapat:

a. mengajukan keberatan kepada LPS yang didukung dengan bukti nyata dan jelas; atau

b. melakukan upaya hukum melalui pengadilan.

(2) Dalam hal LPS menerima keberatan nasabah penyimpan atau pengadilan mengabulkan upaya hukum nasabah penyimpan sebagaimana dimaksud pada ayat (1), LPS hanya membayar simpanan nasabah tersebut sesuai dengan penjaminan berikut bunga yang wajar.

Penjelasan Pasal 20 Ayat 2 UU LPS menyebutkan, pembayaran bunga yang wajar dimaksudkan untuk mengganti kerugian akibat hilangnya kesempatan berinvestasi dan LPS tidak membayar ganti rugi yang lain. Tingkat bunga yang wajar adalah tingkat bunga yang pada umumnya berlaku atas simpanan.

Pada Pengumuman LPS terkait Penetapan Tingkat Bunga Penjaminan Periode Juni 2018, dijelaskan, bahwa kebijakan evaluasi tingkat bunga penjaminan untuk simpanan dalam rupiah dan valuta asing di Bank Umum serta untuk simpanan dalam rupiah di BPR ditetapkan dengan memperhatikan perkembangan suku bunga simpanan bank benchmark yang bergerak naik setelah stabil dalam 3 periode evaluasi sebelumnya. Sesuai ketentuan LPS, apabila suku bunga simpanan yang diperjanjikan antara bank dengan nasabah penyimpan melebihi tingkat bunga penjaminan simpanan, maka simpanan nasabah dimaksud menjadi tidak dijamin. Berkenaan dengan hal tersebut, bank diharuskan untuk memberitahukan kepada nasabah penyimpan mengenai tingkat bunga penjaminan simpanan yang berlaku dengan menempatkan informasi dimaksud pada tempat yang mudah diakses nasabah penyimpan. Sejalan dengan tujuan melindungi nasabah dan memperluas cakupan penjaminan, LPS menghimbau agar perbankan lebih memperhatikan ketentuan tingkat bunga penjaminan simpanan dalam rangka penghimpunan dana. Dalam menjalankan usahanya, bank hendaknya memperhatikan kondisi likuiditas ke depan. Bank diharapkan mematuhi ketentuan pengelolaan likuiditas perekonomian oleh Bank Indonesia serta pengaturan dan pengawasan perbankan oleh OJK.

Merujuk pada uraian tersebut, maka Surat Edaran LPS tentang Penetapan Tingkat Bunga Penjaminan Simpanan yang keabsahannya merujuk pada UU LPS dan Peraturan Lembaga Penjamin Simpanan Nomor 2 Tahun 2014 tentang Perubahan atas Peraturan Lembaga Penjamin Simpanan Nomor 2/PLPS/2010 tentang Program Penjamin Simpanan digunakan sebagai rujukan dalam menetapkan suku bunga simpanan oleh perbankan. Penetapan suku bunga tersebut didasarkan pada monitoring dan evaluasi pada periode sebelumnya.

Suku bunga penjaminan bukan merupakan instrumen yang ditujukan untuk pengendalian moneter. Bahwa dalam prakteknya ada yang mengaitkan tentu bukan berarti itu merupakan tujuan dari LPS. Secara kelembagaan tujuan LPS dalam 
menetapkan suku bunga penjaminan adalah dalam kerangka kewajiban LPS membayar klaim. Tentu ada juga kaitannya dalam rangka menjaga tingkat kepercayaan perbankan dimana obyek penjaminan LPS berada. Ini sesuai dengan amanat UU LPS pasal 4 dimana salah satu fungsi LPS adalah turut aktif dalam memelihara stabilitas sistem perbankan. ${ }^{34}$ Tabel berikut adalah penetapan tingkat bunga penjaminan simpanan untuk Bank Umum dan Bank Perkreditan Rakyat yang ditetapkan LSP melalui SE-nya periode 2015-2021.

Tabel 1. Tingkat bunga penjaminan simpanan pada Bank Umum dan Bank Perkreditan Rakyat periode 2015-2021.

\begin{tabular}{|c|c|c|c|c|c|c|c|}
\hline \multirow{3}{*}{ No } & \multirow{3}{*}{ Tahun } & \multirow{3}{*}{ Bulan } & \multicolumn{5}{|c|}{ Bank } \\
\hline & & & & Bank Umun & & Bank P & litan Rakyat \\
\hline & & & Rupiah & Valuta Asing & Nomor SE & Rupiah & Nomor SE \\
\hline \multirow{3}{*}{1} & \multirow{3}{*}{2015} & JAN-MEI & $7,75 \%$ & $1,50 \%$ & No.7/2015 & $10,25 \%$ & No.6/2015 \\
\hline & & MEI-SEP & $7,75 \%$ & $1,50 \%$ & No.11/2015 & $10,25 \%$ & No.10/2015 \\
\hline & & OKTOBER & $7,50 \%$ & $1,25 \%$ & No.21/2015 & $10,00 \%$ & No.22/2015 \\
\hline \multirow{3}{*}{2} & \multirow{3}{*}{2016} & JAN-MEI & $7,50 \%$ & $1,25 \%$ & No.8/2016 & $10,00 \%$ & No.2/2016 \\
\hline & & JUN-SEP & $6,75 \%$ & $0,75 \%$ & No.13/2016 & $9,25 \%$ & No.12/2016 \\
\hline & & SEPTEMBER & $6,25 \%$ & $0,75 \%$ & No.19/2016 & $8,75 \%$ & No.20/2016 \\
\hline \multirow{3}{*}{3} & \multirow{3}{*}{2017} & JAN-MEI & $6,25 \%$ & $0,75 \%$ & No.1/2017 & $8,75 \%$ & No.2/2017 \\
\hline & & MEI-SEP & $6,25 \%$ & $0,75 \%$ & No.9/2017 & $8,75 \%$ & No.10/2017 \\
\hline & & SEPTEMBER & $6,00 \%$ & $0,75 \%$ & No.18/2017 & $8,50 \%$ & No.17/2017 \\
\hline \multirow{5}{*}{4} & \multirow{5}{*}{2018} & JAN-MEI & $5,75 \%$ & $0,75 \%$ & No.1/2018 & $8,25 \%$ & No.2/2018 \\
\hline & & JUN-SEP & $6,00 \%$ & $1,25 \%$ & No.7/2018 & $8,50 \%$ & No.8/2018 \\
\hline & & JUL-SEP & $6,25 \%$ & $1,50 \%$ & No.9/2018 & $8,75 \%$ & No.10/2018 \\
\hline & & SEPTEMBER & $6,50 \%$ & $2,00 \%$ & No.13/2018 & $9,00 \%$ & No.14/2018 \\
\hline & & OKTOBER & $6,75 \%$ & $2,00 \%$ & No.17/2018 & $9,25 \%$ & No.16/2018 \\
\hline \multirow{5}{*}{5} & \multirow{5}{*}{2019} & JAN-MEI & $7,00 \%$ & $2,25 \%$ & No.1/2019 & $9,50 \%$ & No.2/2019 \\
\hline & & MEI-SEP & $7,00 \%$ & $2,25 \%$ & No.9/2019 & $9,50 \%$ & No.10/2019 \\
\hline & & JUL-SEP & $6,75 \%$ & $2,25 \%$ & No.13/2019 & $9,25 \%$ & No.14/2019 \\
\hline & & SEPTEMBER & $6,50 \%$ & $2,00 \%$ & No.17/2019 & $9,00 \%$ & No.18/2019 \\
\hline & & NOVEMBER & $6,25 \%$ & $1,75 \%$ & No.21/2019 & $8,75 \%$ & No.22/2019 \\
\hline \multirow{4}{*}{6} & \multirow{4}{*}{2020} & JAN-MEI & $6,00 \%$ & $1,75 \%$ & No.1/2020 & $8,50 \%$ & No.2/2020 \\
\hline & & MEI-SEP & $5,00 \%$ & $1,50 \%$ & No.9/2020 & $8,00 \%$ & No.10/2020 \\
\hline & & OKTOBER & $5,00 \%$ & $1,25 \%$ & No.17/2020 & $7,50 \%$ & No. $18 / 2020$ \\
\hline & & NOVEMBER & $4,50 \%$ & $1,00 \%$ & No.21/2020 & $7,00 \%$ & No. $22 / 2020$ \\
\hline \multirow[b]{2}{*}{7} & \multirow[b]{2}{*}{2021} & JAN-MEI & $4,50 \%$ & $1,00 \%$ & No.1/2021 & $7,00 \%$ & No.2/2021 \\
\hline & & FEB-MEI & $4,25 \%$ & $0,75 \%$ & No.5/2021 & $6,75 \%$ & No.6/2021 \\
\hline
\end{tabular}

Sumber: Surat Edaran LPS tentang Penetapan Tingkat Bunga Penjaminan Simpanan periode 2015-2021

${ }^{34}$ Krisna Wijaya, "Lembaga Penjamin Simpanan - Suku Bunga Penjaminan - Artikel," accessed March 12, 2021, https://lps.go.id/artikel/-/asset_publisher/0S8e/content/suku-bungapenjaminan. 
Merujuk pada rekapan penetapan tingkat bunga penjaminan simpanan melalui Surat Edaran dari LPS, maka penetapan tingkat bunga simpanan untuk Bank Umum dan Bank Perkreditan Rakyat dalam ketentuan tersebut dapat diterapkan dalam penetapan tingkat bunga penghimpunan dana berupa simpanan dan tabungan atau istilah yang digunakan adalah investasi oleh KSP. Caranya dengan mengkonstruksi fungsi 'bank dengan $\mathrm{KSP}^{\prime}$ yang menghimpun dana berupa simpanan atau tabungan sebagai dana yang dipercayakan oleh masyarakat kepada bank atau KSP berdasarkan perjanjian penyimpanan dana dalam bentuk tabungan dan atau bentuk lainnya yang dipersamakan dengan itu, mengingat dalam praktiknya KSP juga menghimpun dana dari masyarakat non-anggota. Bank memiliki fungsi intermediasi. KSP sebagai koperasi yang melaksanakan kegiatan usahanya hanya usaha simpan pinjam juga memiliki fungsi intermediasi hanya dikhususkan untuk anggota, walaupun dalam praktiknya program investasi KSP secara terbuka diperuntukkan untuk non-anggota juga.

Oleh karena itu, penetapan suku bunga simpanan atau investasi oleh KSP seharusnya merujuk pada Surat Edaran LSP terkait Penetapan Tingkat Bunga Penjaminan Simpanan, sehingga tidak melampaui kewajaran dan dapat diminimalisir penetapan bunga tinggi oleh KSP. Kementerian Koperasi dan UKM sejatinya juga memberi rambu-rambu kepada KSP yang menyelenggarakan program investasi agar mendorong KSP merujuk pada Surat Edaran LPS tersebut.

Kementerian Koperasi dan UKM sebaiknya dapat melakukan koordinasi yang lebih komprehensif dengan pemerintah daerah provinsi/ kabupaten/ kota dalam mengawasi kinerja KSP. Seperti yang dikemukakan Prastowo \& Julianty dalam artikel Nurita Indriawati, mengingat pentingnya peran koperasi dalam kehidupan sehari-hari, maka perlu pula dilakukan evaluasi terhadap kinerja koperasi. Hal ini perlu dilakukan karena KSP yang merupakan sebuah lembaga financial intermediary dapat dikontrol kesehatannya sehingga dapat dianalisis faktor-faktor yang menghambat kesehatannya dan memperbaiki kinerja KSP tersebut. ${ }^{35}$

\section{Kesimpulan}

Peraturan perundang-undangan yang mengatur mengenai investasi yang dilakukan KSP tidak cukup memadai khususnya berkaitan dengan penetapan suku bunga investasi sehingga masih banyak KSP yang menetapkan bunga tinggi dalam program investasinya karena diserahkan pada RAT, sehingga memungkinkan ditetapkannya bunga secara beragam dan diluar kewajaran. Pada peraturan terbaru yaitu UndangUndang Nomor 11 Tahun 2020 tentang Cipta Kerja dan peraturan pelaksananya yaitu Peraturan Pemerintah Nomor 7 Tahun 2021 tentang Kemudahan, Perlindungan dan Pemberdayaan Koperasi dan Usaha Mikro Kecil dan Menengah, juga tidak mengakomodasi ketentuan tentang program investasi yang dapat dilakukan KSP. Ketentuan tentang koperasi secara umum yang juga berlaku untuk KSP pada 2 ketentuan yang disebutkan terakhir berupa ditetapkannya syarat minimal 9 orang untuk mendirikan koperasi primer dan dibukanya pelayanan koperasi kepada nonanggota seolah menghidupkan kembali ruh Undang-Undang Nomor 17 Tahun 2012

\footnotetext{
${ }^{35}$ Nurita Indriawati, Agung Winamo, and Trisetia Wiïjayanti, “Tingkat Kesehatan Koperasi Simpan Pinjam Dan Faktor Yang Mempengaruhinya," Ekonomi Bisnis 22, no. 1 (2017): 35-43.
} 
tentang Perkoperasian yang dinyatakan oleh Mahkamah Konstitusi telah bertentangan dengan UUD 1945 dan dinyatakan tidak mempunyai kekuatan hukum mengikat.

Ketidakjelasan ketentuan tentang penetapan suku bunga investasi khususnya PP tentang Pelaksanaan Kegiatan Usaha Simpan Pinjam oleh Koperasi dan PermenKUKM Nomor 15/Per/M.KUKM/Ix/2015 tentang Usaha Simpan Pinjam oleh Koperasi, sebagai landasan hukum diperbolehkannya KSP menyelenggarakan program investasi, mengakibatkan KSP secara liar menetapkan suku bunga investasinya. Konstruksi hukum dapat dilakukan dengan merujuk pada penetapan suku bunga simpanan yang ditetapkan oleh Lembaga Penjamin Simpanan melalui serangkaian Surat Edaran yang diterbitkan untuk Bank Umum dan Bank Perkreditan Rakyat.

\section{Ucapan terima Kasih (Acknowledgments)}

Artikel ini merupakan luaran penelitian dengan Nomor Kontrak: 100/B.04/LPPM/XII/2020. Ucapan terima kasih dihaturkan kepada LPPM Unisba sehingga dapat terlaksananya penelitian ini. Ucapan yang sama dihaturkan kepada staf khusus Kementerian Koperasi dan UKM atas kesediannya dalam berdiskusi secara virtual berkaitan dengan penyelenggaraan investasi oleh KSP.

\section{Daftar Pustaka}

$\underline{\text { Buku }}$

Asshiddiqie, Jimly. "Konstitusi Ekonomi." Penerbit buku Kompas, Jakarta, 2010.

Mertokusumo, Sudikno. Mengenal Hukum; Suatu Pengantar. Yogyakarta: Liberty, 2007.

- - - . Penemuan Hukum: Sebuah Pengantar. Yogyakarta: Liberty, 2009.

Partomo, Sartika. Ekonomi Koperasi. Bogor: Ghalia Indonesia, 2009.

S, Sastrawidjaja Man. "Beberapa Perubahan Undang-Undang Nomor 17 Tahun 2012 Tentang Perkoperasian." In Peran Hukum Dalam Pembangunan Di Indonesia: Kenyataan, Harapan, Dan Tantangan, Liber Amicorum Prof. Dr. Etty R. Agoes, SH., LL.M, Bandung: Remaja Rosdakarya, 2013

\section{Jurnal}

Biasin, Massimo. "The German Cooperative Banks. An Economic Overview." In Credit Cooperative Institutions in European Countries, 83-110. Springer, 2016.

Borda-Rodriguez, Alexander, and Hazel Johnson. "Inclusive Development and CoOperatives." European Journal of Development Research 32, no. 4 (September 1, 2020): 976-97. https://doi.org/10.1057/S41287-019-00249-9.

Brazda, Johann, Holger Blisse, and Robert Schediwy. "Cooperative Banks in the Austrian Banking System." In Credit Cooperative Institutions in European Countries, 3-18. Springer, 2016.

Indriawati, Nurita, Agung Winarno, and Trisetia Wijijayanti. "Tingkat Kesehatan Koperasi Simpan Pinjam Dan Faktor Yang Mempengaruhinya." Ekonomi Bisnis 22, no. 1 (2017): 35-43.

Karafolas, Simeon. "The Greek Cooperative Credit System." In Credit Cooperative Institutions in European Countries, 111-26. Springer, 2016.

Kleanthous, Akis, and Athanasios Hadjimanolis. "Co-Operative Credit Institutions in Cyprus." In Credit Cooperative Institutions in European Countries, 19-41. Springer, 2016. 
Kurniawan, I Gede Hartadi. "Tindakan Koperasi Simpan Pinjam Yan Mengakibatkan Perbuatan Tindak Pidana." Lex Jurnalica 10, no. 1 (2013): 18070.

Loubere, Nicholas, and Heather Xiaoquan Zhang. "Co-Operative Financial Institutions and Local Development in China." Journal of Co-Operative Organization and Management 3, no. 1 (2015): 32-39.

McKillop, Donal, Declan French, Barry Quinn, Anna L Sobiech, and John O S Wilson. "Cooperative Financial Institutions: A Review of the Literature." International Review of Financial Analysis 71 (2020): 101520.

Nthaga, Laone Gosego. "An Analysis of the Profitability and Sustainability of Savings and Credit Co-Operatives in Botswana." University of Cape Town, 2018.

Oktaviani Suendra, Dessy Lina. "Pertanggungjawaban Pidana Koperasi Dalam Tindak Pidana Melakukan Kegiatan Perbankan Tanpa Ijin." Jurnal Magister Hukum Udayana 4, no. 2 (n.d.): 44152.

Rabong, Gregor, and Stefan Radakovics. "The Uniform Co-Operative Value CoreEvidence from Austria." Journal of Co-Operative Organization and Management 8, no. 2 (2020): 100118.

Restakis, John. Humanizing the Economy: Co-Operatives in the Age of Capital. New Society Publishers, 2010.

Simmons, Richard, and Marija Nikolic. "Credit Co-Operatives in Serbia: Retrospect and Prospect." In Credit Cooperative Institutions in European Countries, 379-404. Springer, 2016.

Š́uertová, Elena. "Credit Co-Operatives in Slovakia." In Credit Cooperative Institutions in European Countries, 405-17. Springer, 2016.

Waiganjo, Maina, Serah Wanyoike, and Evans Koitaba. "Effect of Compliance to Sacco Regulatory Authority (SASRA) Regulations on Financial Performance of Deposit Taking Savings and Credit Co-Operatives (SACCO) Kenya." Journal of Economics, Management and Trade, 2016, 1-6.

Widiastuti, Widiastuti. "Urgensi Amandemen Undang Undang Perkoperasian." Jurnal Wacana Hukum 8, no. 1 (2009): 23542

\section{Online/World Wide Web:}

Ali Mustofa. "Analisis Hukum Kasus Hanson, Himpun Dana Masyarakat Berkedok Koperasi." Accessed March 3, 2020. https://www.lawjustice.co/artikel/82238/analisis-hukum-kasus-hanson-himpun-danamasyarakat-berkedok-koperasi/.

Anonymous. "MK Batalkan Undang-Undang Tentang Perkoperasian - ANTARA News," n.d. https://www.antaranews.com/berita/436287/mk-batalkan-undangundang-tentang-perkoperasian.

Aries Wijaksena. "Korban Investasi Bodong Melapor Ke Polda Metro." Accessed October 12, 2020. https://mediaindonesia.com/megapolitan/352194/korbaninvestasi-bodong-melapor-ke-polda-metro.

Caesar Akbar, and Dewi Rina Cahyani. "Kasus Gagal Bayar Koperasi Hanson, Nasabah Tolak Solusi Pengurus - Bisnis Tempo.Co." Accessed January 29, 2020. https://bisnis.tempo.co/read/1301212/kasus-gagal-bayar-koperasi-hansonnasabah-tolak-solusi-pengurus.

Emral Firdiansyah. "Pemahaman Masyarakat Soal Koperasi Simpan Pinjam Masih Minim." Accessed August 8, 2020. https://investor.id/finance/pemahamanmasyarakat-soal-koperasi-simpan-pinjam-masih-minim.

Ferrika Sari, and Khomarul Hidayat. "Kementerian Koperasi Minta Masyarakat 
Waspadai Praktik Shadow Banking Di Koperasi." Accessed June 6, 2020. https://keuangan.kontan.co.id/news/kementerian-koperasi-minta-masyarakatwaspadai-praktik-shadow-banking-di-koperasi.

Ferrika Sari, and Yudho Winarto. "Indef Sebut Gagal Bayar Koperasi Karena Pengawasan Lemah - Page 2." Accessed May 18, 2020. https://keuangan.kontan.co.id/news/indef-sebut-gagal-bayar-koperasi-karenapengawasan-lemah?page $=2$.

Krisna Wijaya. "Lembaga Penjamin Simpanan - Suku Bunga Penjaminan - Artikel." Accessed March 12, 2021. https://lps.go.id/artikel/Lasset_publisher/0S8e/content/suku-bunga-penjaminan.

Maizal Walfajri, and Tendi Mahadi. "Tersangkut Kasus, Koperasi Indosurya Cipta Ikuti Tiga Sidang PKPU." Accessed May 3, 2020. https://keuangan.kontan.co.id/news/tersangkut-kasus-koperasi-indosuryacipta-ikuti-tiga-sidang-pkpu

Redaksi. "Kreditur Setujui Proposal Perdamaian Debitur KSP Pracico Inti Sejahtera Dalam Proses PKPU Sementara | Vonisinvestigasi.Co.Id," n.d. https://www.vonisinvestigasi.co.id/2021/01/12/kreditur-setujui-proposalperdamaian-debitur-ksp-pracico-inti-sejahtera-dalam-proses-pkpu-sementara/.

Thomas Mola. "Investasi Bodong Berkedok Koperasi Kian Marak - Ekonomi Bisnis.Com." Accessed March 2017. https://ekonomi.bisnis.com/read/20170317/87/637992/investasi-bodongberkedok-koperasi-kian-marak.

Sylke Febrina Laucereno. "Ini 12 Koperasi Abal-Abal Yang Bikin Buntung." Accessed December 14, 2018. https://finance.detik.com/moneter/d-4329974/ini-12koperasi-abal-abal-yang-bikin-buntung.

Walfajri, Maizal, and Herlina Kartika Dewi. "PKPU Koperasi Bertambah, Begini Penjelasan Kemenkop UKM - Page All." Accessed September 3, 2020. https://keuangan.kontan.co.id/news/pkpu-koperasi-bertambah-beginipenjelasan-kemenkop-ukm?page=all. 